\title{
10 DINÂMICA DOS ENCONTROS DE MEDIAÇÃo
}

Cada família encaminhada a mediação é atendida uma vez por mês ${ }^{41}$, os encontros de mediação acontecem uma vez por semana e duram em torno de duas horas. Normalmente o processo de mediação leva por volta de seis encontros; este número pode variar, dependendo de cada caso. Quando os encontros resultam em um acordo ou termo de entendimento, são feitos mais um ou dois encontros de acompanhamento.

São desenvolvidas todas as etapas da mediação: Pré-mediação; Etapa I - Organização do Processo; Etapa II - Relato dos Mediados; Etapa III - Construção da Agenda; Etapa IV - Fechamento do Processo ${ }^{42}$. Essas etapas serão apresentadas em tópicos posteriores.

Além dos encontros em que todos os participantes se reúnem, é trabalhada pelos mediadores a possibilidade de encontros separados, chamados cáucus ${ }^{43}$, que

41 Os atendimentos acontecem uma vez ao mês por solicitação das famílias mediadas, para não serem prejudicadas em faltas no trabalho, no horário da mediação recebem atestado de comparecimento. Os intervalos mensais entre os encontros também favorecem aos combinados que os mediados realizam durante os encontros.

42 INSTITUTO FAMILIAE, 2010, p. 14-36.

43 "Caucus: são os encontros privados dos mediadores com cada mediando, individualmente. Esses encontros podem acontecer após a decisão de todos os envolvidos em participar da mediação e a qualquer tempo no curso da mediação. A decisão sobre a utilização ou não dessa ferramenta de trabalho caberá aos mediadores, ou quando for solicitada por, pelo menos, um mediando" (GROSMAN e MALDELBAUN, 2011, p. 319). 
podem acontecer a qualquer momento, tanto por solicitação dos mediandos quanto dos mediadores, que podem consultar se os participantes possuem interesse em conversar separadamente sobre o conflito. No caso da ocorrência de cáucus, o número de encontros pode ultrapassar seis.

Durante os atendimentos, as principais ferramentas trabalhadas pelos mediadores são o rapport, a escuta ativa e perguntas. $\mathrm{O}$ rapport se traduz em acolhimento, bem receber e no não julgamento. A escuta ativa é a escuta atenta e cuidadosa dos mediadores, que possibilita empatia e confiança por parte dos mediados e o desenvolvimento das perguntas. Nesse sentido, Almeida, T. esclarece:

A Escuta Ativa apoia-se no tripé legitimação, balanceamento e perguntas e tem por objetivos: (i) oferecer uma qualidade de interlocução cujo acolhimento possibilite que as pessoas se sintam legitimadas em seus aportes e participação; (ii) conferir equilíbrio entre dar voz e vez aos integrantes da conversa e viabilizar uma escuta que inclua o ponto de vista do outro; (iii) oferecer perguntas que gerem informação, propiciem progresso e movimento ao processo de Mediação (2014, p. 66).

Com relação aos tipos de perguntas feitas pelo mediador, Parkinson exemplifica:

- Abertas: convida a uma resposta genérica ou espontânea: "Então o que vocês esperam da mediação?"

- Indireta: pode ser respondida por qualquer das partes: "Vocês têm algum acordo em andamento?"

- Perguntas sobre opções: "Vocês conseguem enxergar outras possibilidades?"

- Perguntas para esclarecer as prioridades e facilitar a comunicação: Qual é a sua principal prioridade agora? (2016, p. 201-202).

\subsection{PRÉ-MEDIAÇÃo}

$\mathrm{Na}$ pré-mediação, os mediadores de campo realizam a fala de abertura, na qual: apresenta-se o risco em que o idoso se encontra; explica-se que os membros daquela família foram convidados para trabalharem a comunicação familiar e os cuidados com o idoso; informa-se como serão os encontros e se comunicam os princípios da mediação e princípios éticos do mediador. Os mediadores estabelecem com os participantes como será a organização das falas e já iniciam uma primeira escuta do problema a partir do ponto de vista da família.

Se houver tempo, ao final deste encontro faz-se uma leitura do Termo de Adesão, esclarecendo aos participantes do que se trata. O Termo de Adesão ${ }^{44}$ é um

44 Conforme transcrição do Termo de Adesão na p. 167, no final deste livro 
documento em que se explica o que é a mediação, apresentam-se seus princípios e se explicitam as exceções com relação à confidencialidade. Esse documento é lido e assinado pelos mediandos, para firmar seu compromisso em participar do processo de Mediação.

\subsection{RELATOS DAS HISTÓRIAS OU FASE DAS NARRATIVAS}

As famílias que comparecem à Mediação para Idosos costumam ser numerosas, e há duas formas mais frequentes em que o conflito se apresenta: ou o conflito gira em torno especialmente de dois mediandos - entre dois irmãos, ou entre um dos pais e um dos filhos -, ou a família já chega dividida em dois lados, com duas opiniões pré-determinadas. Em ambos os casos, essa divisão de opiniōes afeta todos os membros da família de tal forma que, quando chegam aos primeiros encontros, os familiares estão muito envoltos no conflito e possuem dificuldades tanto em se reunirem, quanto em contarem suas histórias. Durante o caminhar da mediação, as ferramentas comunicativas são trabalhadas pelos mediadores de campo para a ampliação das narrativas.

Como são vários os presentes, os mediadores procuram equilibrar o tempo de escuta e escolher perguntas que possam contemplar a todos, para que todos se sintam inseridos e participantes do processo. Quando acontece a necessidade de um encontro privado, a mesma oferta é feita a todos, com distribuição igual de tempo para cada participante. $\mathrm{O}$ cáucus pode acontecer em um mesmo dia, quando vários mediandos são escutados em separado, ou em dias separados, quando comparece ao encontro apenas o participante a ser ouvido.

Durante as narrativas dos participantes, os mediadores, por meio de perguntas, procuram trabalhar os princípios do empoderamento e da autodeterminação de todos os mediandos. Entende-se por empoderamento o protagonismo e fortalecimento dos mediandos para encontrarem soluçôes para os impasses que vivenciam; e por autodeterminação, a possibilidade de eles próprios chegarem a construçôes de alternativas possíveis.

Nesta fase, os mediadores escutam atentamente as diversas histórias que cada mediando traz, a partir da escuta ativa, do não julgamento, do cuidado com sua imparcialidade e com sua postura não verbal; para facilitarem o processo narrativo, utilizam ferramentas como perguntas, validação, recontextualização, resumo e visita ao lugar do outro.

Segundo Almeida, T. (2014):

- As perguntas "são a intervenção mais significativa em mecanismos autocompositivos, uma vez que têm a intenção de gerar reflexão, informação e ideias-alicerces desta natureza de processo" (p. 75). 
- A validação "tem por objetivo legitimar, no sentido de justificar positivamente" (p. 69).

- Recontextualizar é: "redefinir, definir novamente", "é encontrar motivação legítima ou intenção positiva no que foi dito ou feito” (p. 281).

- Resumo: "destina-se a condensar um certo volume de fala e dela selecionar o que a subjetividade do mediador considera significativo/relevante para o caso em um determinado momento" (p. 284).

- Visitar o lugar do outro: "imaginar-se em situação ou posição semelhante no presente, ou no futuro; promover a reflexão” (p. 279).

\subsection{CONSTRUÇÃO DA AGENDA}

Esta fase é chamada de construção da agenda ou de busca de opções de soluções. Esta etapa acontece quando os mediandos conseguem refletir no que podem fazer para se melhorar a situação em que o idoso se encontra e para aprimorarem a comunicação familiar. São utilizadas pelos mediadores as técnicas da negociação de Harvard, baseadas em princípios que têm como pontos fundamentais (FISHER, et al. 2006 p. 28):

- Separar as pessoas do problema: para que os mediandos reflitam qual é problema comum que possuem.

- Focar nos interesses e não nas posições: posições são as falas que os mediandos trazem; os mediadores trabalham com perguntas sobre quais são os reais interesses que possuem, o que está oculto em suas falas.

- Gerar opções, buscar pontos comuns: a mediação não caminha nos impasses - somente consegue avançar nos pontos que são positivos e comuns.

- Utilização de critérios que sejam objetivos nas soluções encontradas pelos mediandos - que necessitam ser possíveis de acontecerem na prática; os mediadores atuam como agentes de realidade: por exemplo, na contratação de um cuidador, as perguntas são de como serão os detalhes dessa contratação (horário de trabalho, pagamento, divisão das despesas, etc.).

\subsection{ENCERRAMENTO DO PROCESSO}

Quando acontecem todos os encontros e/ou quando é possível o desenvolvimento de todas as fases, a mediação se encerra com a etapa final, que é o fechamento do processo.

Quando a comunicação familiar é restabelecida e são possíveis se estruturar em combinados, estes são redigidos em um Acordo ou Termo de Entendimen- 
to ${ }^{45}$, um documento com um breve relato do processo de mediação e com os acordos feitos, que é lido para os mediandos.

Após a finalização do Acordo, pode ser agendado um encontro com o Promotor de Justiça responsável pelo Procedimento Administrativo para ciência dos combinados e validação das decisões, quando se conferem novamente as proposiçóes, com a possibilidade da homologação e constituição de um título executivo extrajudicial, a partir do qual uma das partes pode exigir da outra o cumprimento da obrigação assumida.

45 O Termo de Entendimento acontece quando são realizados combinados na Mediação entre um filho (ou filha) e o idoso (ou idosa). 
